\title{
Francesca Vessia
}

https://orcid.org/0000-0002-5386-7607

Law Department

University of Bari Aldo Moro, Italy

francesca.vessia@uniba.it

\section{Towards Consumer Social Responsibility}

Accepted by Editor Ewa Ziemba | Received: November 7, 2018 | Revised: June 15, 2019; October 15, 2019 | Accepted: October 20, 2019.

\begin{abstract}
Aim/purpose - This paper aims at investigating the existence of Consumer Social Responsibility (CSR), legally based on the second-generation EU consumerist legislation, which affects companies deeply in fulfilling socially responsible choices of business.

Design/methodology/approach - The method followed-up of CSR is a bottom-up perspective inspired by matching corporate social responsibility with consumer social responsibility. Among consumers a strategic role is entrusted to the 'state' that is named in this paper 'superconsumer'.

Findings - It is argued that a juridical consumer responsibility may be affirmed as part of a European strategy to inspire voluntary sustainable choices by corporations, imposing a social responsibility for consumers from the bottom. Pieces of evidence are collected throughout three sectors of EU legislation: financial market, energy environment and public procurement.

Research implication/limitation - The implication of this research consists in drawing a path of inference from the well-known rights of consumers to their duties including consumers' social responsibilities. The most significant limitation of the study is its restriction on investigating only three sample domains among larger sectors within EU consumer law and preferably Italian law. A subsequent development of this research will fill this gap by broadening the investigation field.

Originality/value/contribution - There are no previous studies in Italy and in European literature concerning the role of consumer law in affecting CSR and, more generally, in the European juridical literature on CSR about the influence of consumers' legal responsibility on socially responsible choices of companies. In addition, it leads on to the original idea of the existence of juridical consumers' duties inferred by consumers' rights as the inseparable effect of consumers' empowerment.
\end{abstract}


Keywords: CSR, citizen-consumer, Consumer Social Responsibility, energy savings, ethics and sustainable financial products, environment and green procurement law.

JEL Classification: K20.

\section{Introduction}

This paper is driven by a double recognition. First and foremost, being aware that there have been done some attempts by the legislator in the last few years to give Consumer Social Responsibility (CSR) the character of a legal form of corporate governance, thus overcoming its traditional characters, voluntariness and non-binding (Angelici, 2011, 2018; Denozza, 2013; Denozza $\&$ Stabilini, 2017a) which are at an experimental level. Some examples of this are the benefit corporation (Denozza \& Stabilini, 2017b) introduced in the American and Italian experience (Law no. 208/2015 - known as the 2016 Stability Law - art. 1, pars. 376-384), as well as the new notion of 'ethical and sustainable finance operator'(par. 3) introduced into the Italian Single Banking Text (TUB, article 111-bis, by emendation of Law of 11 December 2016, no. 232), while at a EU level another example is the regulation of non-financial information Directive 2013/34/UE already implemented both in Europe and in Italy (Assonime, 2016; Legislative Decree, 30 December 2016, no. 254; Malaguti \& Salvati, 2017).

Furthermore, it is a common belief that business decisions of enterprises are more and more influenced by consumption choices (as it was already written in the 1980s on the interaction between stakeholder thinking and enterprise, that had been previously expected (Freeman, 1984)), therefore enterprises came to be influenced by the degree of awareness and ethical responsibility expressed to them by consumers, with a cross impact on both small and large enterprises, although to a different extent (Libertini, 2013).

Consumers have in fact the power to influence industrial plans and enterprise lines of production: think of Palm oil that, as an ingredient 'criticised' and unwelcome to the masses, has been 'banned' from almost all food products of large retail chains. Another example is the growth of the hybrid car sector with the consequent decline of the diesel one that is shifting the axis of programming of all the companies of the automotive sector. Next, we can point out to the growth of the market for organic products, now no longer the prerogative of a retailers' niche but of large-scale retail trade with a cross-cutting impact on both small and large companies, albeit to a different extent. 
The most significant expression of this power of a consumer as a citizen is that used by the German economist Beck, who assimilates consumption choices to the ballot papers: 'the citizen discovers the buying act as a direct ballot sheet which can be always and everywhere applied politically' (Beck, 1997). However, the phenomenon of 'a political consumerism' is much more evident over time, understood as a movement of citizens committed to pursuing political campaigns through their own market choices as consumers: think of the American civil rights movement, the struggle of Mahatma Gandhi for self-rule in India, the struggle against apartheid in South Africa and so on (Micheletti, 2002).

Starting from this bottom-up perspective of CSR, understood in the sense of Consumer Social Responsibility rather than Corporate Social Responsibility and making the concept of 'responsible' consumer (frequently used in international and European documents on sustainable development as well as in economic, sociological and political sources of the last fifteen years) the pivot of this research. We will seek to analyse a legal basis to consumer social responsibility with a twofold objective: on one hand, to provide a new meaning of CSR emancipated from the limits of ethics and morality, as traditionally and commonly has been done and on the other, demonstrate the role of CSR as an economic propulsion towards socially responsible corporate choices, though still voluntary.

This outcome will be achieved, firstly, by exploring the literature related to the legal rights of consumers of which the existence of social ethical duties of consumers has been inferred. Thereafter, we will discuss the research methodology based on the possibility to design a new framework of legal duties for consumers, passing through the investigation of three special sectors of the so-called second generation consumers regulation: energy, finance, as well as environmental and public procurement sectors. Next, we will examine the findings of the designing a new framework of consumers' legal duties and the relationship of the consumer social responsibility, based on legal duties, and the corporate social responsibility, still based on mostly ethical and voluntary decisions. Lastly, our goal will be to demonstrate by means of legal interpretation of these rules that they may underpin the idea of an induction of socially responsible corporate decisions starting by the assignment of legal duties to consumers, especially institutional ones like the government and all public entities which are called 'superconsumers' in this paper. 


\section{Literature review}

The starting observation is that the EU consumer regulation, after the first season of 'paternalism,' aimed at protecting the consumer as 'a weak contractor' who appeared to be in need of recognition of multiple rights to balance the overwhelming bargaining power of enterprises - has moved its focus to consumers' empowerment since the end of the second millennium, drawing in Directives and Regulations of (so-called) second generation a model of active consumer able to be a market player (well) 'informed, aware and responsible' concerning not only economic, but also environmental, social and ethical involvements of their consumption choices ${ }^{6}$.

This new functionalisation of European sources, re-oriented towards a new kind of 'responsible' consumer, has grown together with the emergence of the economic, sociological and political ideas of a consumer as a citizen or a citizen-consumer (Cseres \& Schrauwen, 2012; Foltyn-Zarychta \& Zerbe, 2019; Hilton, 2005; Micheletti, 2002; Schrader, 2007; Vanderheiden, 2010), capable of making decisions that are not just selfish but rather influenced by ethical values and an altruistic perspective, in the role of citizen, evaluating the impact of their own political choices in a systematic key.

However, international organisations moved in the same direction to affirm a 'consumer responsibility' through sources of soft law as the Guidelines for promoting consumer education, which, in 2005, were issued by the Consumer Citizenship Network $(\mathrm{CCN})$ - an European network of researchers, institutions and civil organisations of 30 different EU states - as well as the OECD research from 2007 on 'CSR and Trade' (Fliess, Lee, Dubreuil, \& Agatiello, 2007) that emphasise the importance of communication and information for consumers about increasing responsible choices towards the environment and society.

This ideas has developed in parallel with the trend against the well-known international promotion actions of CSR for big multinational enterprises, as for

6 Principal EU documents which can be deemed within the 'second generation' cluster are: Regulation (EC) no. 713/2009, 13 July 2009 establishing an Agency for the Cooperation of Energy Regulators; Regulation (EC) no. 714/2009, 13 July 2009 on conditions for access to the network for cross-border exchanges in electricity; Regulation (EC) no. 715/2009, 13 July 2009 on conditions for access to the natural gas transmission networks; Dir. 2009/72/EC, 13 July 2009 concerning common rules for the internal market in electricity; Dir. 2009/73/EC del 13 July 2009 concerning common rules for the internal market in natural gas; Dir. 2012/27/UE del 25 October 2012, on energy efficiency; Regulation (UE) no. 211/2011, 16 February 2011 on the citizens' initiative. Among soft law sources a crucial role plays the Communication of Commission, $\operatorname{COM}(2010) 639$ final, 10.11.2010 Energy 2020. A strategy for competitive, sustainable and secure Energy. 
example the OECD Guidelines for Multinational Enterprises $(2011)^{7}$, the Tripartite Declaration of Principles for multinational enterprises and the social policy of IOL (International Organization of Labor) and the Global Compact, together with the sources of European Law for sustainable development and CSR (Acconci, 2009; Malaguti \& Salvati, 2017).

The outcome of the consumerism law reorientation process around the so-called responsible consumer was to induce a path of inference from the well-known rights of consumers to the duties of them, according to a pattern spread in a literature such as presented in Tables 1 and 2 .

Table 1. Consumer bills of rights and responsibilities

\begin{tabular}{|l|l|}
\hline \multicolumn{1}{|c|}{ Consumer bill of rights } & \multicolumn{1}{c|}{ Consumer bill of responsibilities } \\
\hline 1. Right to safety & 1. Responsibility to use products safely \\
\hline 2. Right to be informed & 2. Responsibility to use information \\
\hline 3. Right to choose & 3. Responsibility to choose carefully \\
\hline 4. Right to be heard & 4. Responsibility to express satisfaction or dissatisfaction \\
\hline 5. Right to redress & 5. Responsibility to seek redress \\
\hline 6. Right to consumer education & 6. Responsibility to be an educated consumer \\
\hline 7. Right to a healthy environment & 7. Responsibility to contribute to a healthy environment \\
\hline
\end{tabular}

Source: Miller \& Stafford (2009).

Table 2. Deriving consumer citizen's duties from consumer rights

\begin{tabular}{|l|}
\hline 1. Right to safety $\rightarrow$ Duty to operate safely \\
\hline 2. Right to be informed $\rightarrow$ Duty to be informed \\
\hline 3. Right to safety $\rightarrow$ Duty to operate safely \\
\hline 4. Right to choose $\rightarrow$ Duty to choose consciously \\
\hline 5. Right to be heard $\rightarrow$ Duty to make oneself heard \\
\hline
\end{tabular}

Source: Schrader (2007).

On the basis of these logical schemes, some models of consumer responsibility will be discussed below concerning three different sectors: finance, energy, environment and green procurement.

7 Promulgated firstly in 1976, the Guidelines for Multinational Enterprises (2011) by OECD were approved by member states rather than by the Council of OECD, updated frequently until the last one in 2011, since then they have the shape of Recommendations to the member states for multinational enterprises regulations. 


\section{Research methodology}

Juridical research like this needs to focus on laws and rules to investigate how they function, which interpretative issues they hide and which interests are destined to be protected. The paper aims at discovering the consumer regulation and its linkage with CSR, as never before, starting from those sectors in which have more recently been implemented consumers' empowerment and, consequently, new legal duties and responsibilities are set onto consumer.

The paper will explore the possibility to design a new framework of legal duties for consumers, investigating of three special sectors of the so-called second generation consumers regulation: the energy sector, the financial sector, and the environmental and public procurement sectors.

The selection of these fields is not accidental. It depends largely upon their extensive regulation due to the strategic role within the European legislation, and thus the harmonisation imposed on countries in the Economic European Space (EES). Under the perspective of a legal researcher, this study scrutinises the role of consumer law in affecting (probably as an involuntary consequence) corporate social responsibility, which might be obtained by analysing the rules of these fields and could be easily translated everywhere in European countries within EES.

Furthermore, the example of Italian implementation of the European legislation in these sectors may be an interesting landmark for other European countries where different juridical solutions might have been adopted.

Another clarification ought to be made to avoid overlapping and blurring of the boundary between legal and ethical duties within the corporate social responsibility and the consumer social one.

Up to now, corporate social responsibility has been understood as a voluntary corporate behaviour beyond legal compliance, following the traditional setting commonly spread in the literature, that we will not discuss in this paper, in spite of the fact that more and more EU legislations are transforming previous ethical responsibilities into legal ones (the disclosure duty of non-financial information embedded in Directives 2013/34/EU (Legislative Decree no. 254/2016) and 2014/95/EU) as well as some national legislations (for example the new type of benefit corporation introduced in Italy by the Law no. 208/2015, art. 1, pars 376-384 on the model of well-known American benefit corporations). A similar tendency of development in CSR can be observed in different countries from East to West, therefore some Authors are approaching the issue whether a mandatory corporate social responsibility is growing or not (Li, 2019). 
Nonetheless, a different approach occurs on the side of consumer social responsibility where we seek to demonstrate the possibility of inferring consumers' duties from a legal basis of consumers' rights, not an ethical one, despite consumers' duties not being explicitly and voluntarily settled by the law, but they may be deemed in their existence by interpreting the law, as we propose to do.

In other words, what we wish to demonstrate is the existence of consumers' legal duties moving from the interpretation of consumers' legal rights, not instead of moving from ethical duties, even if elaborate legal rules absorbing previous ethical prescriptions are a usual practice in the evolution of juridical systems.

Thus, we share the Carroll's (1991) statement, that CSR can be depicted as a pyramid of different types of obligations, distinguishing clearly ethical and legal responsibilities: "ethical responsibilities embrace those activities and practices that are expected or prohibited by social members even though they are not codified into law. [...] In one sense, changing ethics or values precede the establishment of law because they become the driving force behind the very creation of laws or regulations. [...] In another sense, ethical responsibilities may be seen as embracing newly emerging values and norms society expects business to meet" (Carroll, 1991: 41).

The originality of the methodology we propose in researching CSR lies in stating neither the existence of legal duties for firms nor the compulsory nature of CSR, but instead in affirming both the existence of consumers' legal duties moving from consumers' legal rights, as an inseparable consequence of the consumers' empowerment, and, at the same time, the role of these affirmed consumers' legal responsibilities in affecting CSR and more generally in influencing socially responsible choices of firms.

The discontinuity of our proposed point of view compared to Carroll's and other traditional Authors' statements consist in a path of development of CSR not driven by the force of ethical values, which become new legal duties for companies and firms, but rather a CSR driven from a bottom-up nudge which makes firms meet consumers' needs, though these needs do not arise in a spontaneous way but instead are induced by laws in the form of new social legal duties. 


\section{Research findings}

\subsection{Consumers' duties in the financial sector}

As known, the MIFID system has systematised the financial information of intermediaries towards (potential) customers and buyers of financial instruments based on a risk profiling and the principle of the adequacy of risk profile in respect of financial products offered, the so-called adequacy and appropriateness rules (Annunziata, 2015; Pellegrini, 2013; Perrone, 2010; Sciarrone Alibrandi, 2009). In this way, a three-direction-responsibility has been attributed to the buyer of financial instruments, and it could be represented schematically, developing the above-mentioned technique of inferring duties from rights of consumers, as follows:

1) the duty to get informed in advance and comprehensively about the risks of financial products, as well as the intermediary's obligation to give clear, correct, accurate and not misleading information;

2) the duty to provide truthful and detailed information on their financial experience and expertise, as well as on their risk appetite, directly proportional to the profitability and riskiness of financial products;

3) the duty to bear the losses derived from risky investments if all previous information duties have been respected and the financial intermediary, in turn, has respected his duty to conform the financial instruments offered according to the risk profile of the client.

It is also known that, an increasing attention of Authors and Authorities has been paid to the so-called ethical and socially sustainable finance (Capriglione, 1997) in the financial sector, especially in recent years, therefore, in the current Communication of EU Commission (2018) Action Plan: Financing Sustainable Growth (COM(2018) 97 final, 8.3.2018), it is declared that the Commission will re-orient the flows of financial investments towards sustainable economy and 'green' financial instruments $(\operatorname{COM}(2018) 97$ final, $\S \S 2.1$ e 2.2, pp. 4-5). This involves introducing the system of European standards, benchmarks and labels for sustainable economic activities as well as green financial products to ensure that it will be possible to find in financial information notices suitable to meet the purchase needs of an ethically oriented investor. The most commonly used acronym to refer to this type of product is RSI - Responsible Socially Investment or Socially Responsible Investment (Thornton, 2008). 
Consequently, the EU Commission announced in the Action Plan its intention to amend the MIFID II and the IDD (Dir. 2016/97/EU on insurance distribution in force in EES from 23 February 2018) until the end of 2018 but it did not yet happened (COM(2018) 97 final, $\S \S 2.4: 6-7)$ and invited ESMA (European Security and Market Authority) to enclose in its Guidelines (2012) requirements on the sustainability of financial products and the adequacy evaluation with regard to consumers to meet investor preferences in social and environmental subjects as well as in governance factors of the issuing companies. Consequently, ESMA released an updated text of its Guidelines on certain aspects of the MiFID II suitability requirements (6 November 2018).

In this way, informative duties of issuing companies will be increased but, at the same time, also the responsibilities of investors will be expanded, adding with regard to green financial products the following:

1) the duty to give information on their own preferences about ethics, society and environment;

2) the duty to take on the losses arising from the purchase of ethical or socially sustainable products if adequate with risk profile and /or the eco footprint of the investor.

In particular, the assumed risk (under the form of renunciation of proceeding against the intermediary for possible losses) in this case appears increased or duplicated in comparison with non-ecological products: the CSR stands in as a reputation label which is able to improve appeal of less remunerative financial products, therefore the investor takes on both direct and indirect risks. Direct risk is commonly taken by all investors and all financial products, and concerns the economic risk of failing to meet the target or obtaining less profit than expected. Indirect risk is an additional one to fail to achieve the corporate social responsibility objectives predetermined by enterprises.

Therefore, proceeding with a gross synthesis, it is believed that this case can be considered as the first representative of the CSR translation on the consumer in the form of responsibility, not only morally but juridically founded.

Taking the financial sector again into consideration, a partially different, but useful to confirm this idea of CSR translation from enterprises to consumers, case could be identified in ethical banks (Arena, 2008; Costi, 2011).

The new article 111-bis, TUB, implemented by the Law of 11 December 2016 no. 232 (Italian Budget Law 2017), has set a number of requirements for the qualification of ethical and sustainable finance operators, even without explaining the defining boundaries of the two different adjectives employed. Among these, the duty to adopt internationally shared and recognised ethical 
rating standards stands out, paying particular attention to the social and environmental impact on evaluating loans required by juridical bodies and the obligation (textually) to the "devolution of at least twenty percent of its credit portfolio to non-profit organization or to social enterprises" (art. 111-bis of Ethical and sustainable finance).

Referring to another location (Italy) and to other Authors (Sciarrone Alibrandi, \& Macchiavello, 2018) the intent is to trace a few simple functional observations to the discourse of Consumer Social Responsibility. First of all, the Italian Legislator introduced 'ethical' requirements for banks for the first time these include governance requirements and remuneration policies, destination of profits (rectius prohibition of distribution of profits), duties of transparency and disclosure of legal entities financed on an annual basis also through the company website $^{8}$.

Indeed, with regard to the pre-existing article 117-ter Consolidate of Finance Act (Legislative Decree no. 58/1998, TUF) so-called Provisions on ethical finance and corresponding provisions of the Consob Regulation on Intermediaries (2007, articles 89-90), the Italian legislators preferred to omit identifying characters for 'operator' and ethical finance or socially responsible 'products', assuming it is sufficient to introduce duties of disclosure and reporting, being aware of the relativity of the concept itself of ethics and the difficulty of defining ethical investment in its objective content (as explained by Consob (2007) in one of its deliberations ${ }^{9}$ ).

Furthermore, the current definition refers to requirements of 'juridical or normative' ethics - it means what is not authentically ethical because it does not belong to the sphere of values and consciousness - useful to measure the inter-

8 Art. 111-bis Ethical and sustainable finance.

'1. Banks may be deemed as ethical and sustainable finance operators if they conform their activities to the following principles:

a) they have to evaluate loans provided to legal entities under international ethical rating standards, with particular attention to the social and environmental impact;

b) they have to give evidence of loans listed in letter a) at least on an annual basis, also through the company website, according to the law in force for privacy protection;

c) they have to donate at least $20 \%$ of their credit portfolio to non-profit organisations or social enterprises with legal personality, as defined by current legislation;

d) they have to reinvest profits in their own business or don't have to distribute them;

e) they have to adopt a strong democratic and participatory oriented governance system and an organisational model characterised by a widespread shareholding;

f) they have to adopt remuneration policies aimed at minimizing the difference between the higher and the average remuneration of the bank, whose ratio cannot however exceed the value of 5 '.

9 Consob Deliberation 15861 of 30 May 2007. 
ests different from egoistic profit which characterise every business in an objective way. We can derive from it a negative definition of the ethics enterprises (banking and financial): ethical banks carry out the traditional activities of collecting savings and providing loans to satisfy not only the shareholder egoistic and economic interests (profits), but also lato sensu 'altruistic' or simply 'different' interests (Costi, 2011; Sciarrone Alibrandi \& Macchiavello, 2018).

In the context of this legal definition nothing is arranged with regard to loans granted to individuals which consequently will remain within management discretion and the limits of voluntary profiles, which evaluate the choices of banking corporate social responsibility on the authentically 'ethical' level and not legally placed one.

In other words, the more funding will the bank want and/or can provide to individuals (for instance for the purchase of the first house either for the restructuring the old one or to support the costs of energy efficiency improvements in buildings), even the more 'ethical' its reputation will be among consumers and therefore on the social level. The more loans banks will or can provide to ecofriendly legal entities or if their manage to devolve at least 20 percent of their credit portfolio to non-profit organisations or social enterprises, together with other legal requirements, the more 'ethical' they appear on the legal or juridical level.

In this situation, it is not exactly a case of acceptance of social responsibility by the consumer, as in the aforementioned case, but certainly a translation of the 'ethical' qualification on the banking companies as a consequence of ethical choices of the legal entities or individuals who receive loans: if socially responsible entrepreneurs or ethical and socially oriented consumers, rather than socially irresponsible subjects are financed, this is to denote the quality of the enterprise (banking, in this case).

Again, it can be observed a reversal of the perspective of Corporate Social Responsibility in Consumer Social Responsibility, which confirms that an enterprise is responsible on condition that individuals or entities financed by it are socially responsible.

\subsection{Consumers' duties in the energy sector}

It is known that EU institutions, implementing the Kyoto protocol, have made the energy efficiency target one of the headline targets of the Union's new strategy for jobs and smart, sustainable and inclusive growth, according to the 
European Council Conclusions of 17 June 2010 Europe 2020 Strategy. The Commission Communication of 10 November 2010 on Energy 2020 (COM(2010) 639 final) places energy efficiency at the core of the Union energy strategy for 2020 and outlines the need for a new energy efficiency strategy based on the objective of saving by at least $20 \%$ of the Union's primary energy consumption by 2020 compared to projections (and divided into individual objectives for each member state), and concurrently other two commitments to reduce by at least $20 \%$ greenhouse gas emissions and increase by at least $20 \%$ the energy needs from renewable sources ${ }^{10}$.

These energy saving targets were incorporated in the Directive 2012/27/EU on energy efficiency (amending Directives 2009/125/EC and 2010/30/EU and repealing Directives 2004/8/EC and 2006/32/EC), implemented in Italy by the Legislative Decree 4 July 2014, no. 102, and subsequently integrated and renewed by Legislative Decree 18 July 2016, no. 141.

The Italian legislative Decree on energy efficiency (no. 102/2014), and the corresponding Directive 2012, introduced the duty to gradually decrease energy consumption adopting a number of energy efficiency measures to achieve national saving targets up to 2020 (Bonini, 2015; Maugeri, 2014; Parola, Armoni, $\&$ Granata, 2015). The principal measures include a rate of building renovation, "as the existing building stock represents the single biggest potential sector for energy savings. (...) Buildings owned by public bodies account for a considerable share of the building stock and have high visibility in public life. It is therefore appropriate to set an annual rate of renovation of buildings owned and occupied by central government on the territory of a Member State to upgrade their energy performance" (Dir. 2012/27/EU, Whereas 17).

The latter set a rate of building renovation to be achieved, firstly, on buildings owned or occupied by central government, secondly on buildings of public bodies at regional and local level, and lastly also on citizens and big enterprise buildings (more than 250 employees, revenue over $€ 50 \mathrm{~m}$ or financial report over $€ 43 \mathrm{~m}$ ), especially for companies fulfilling electric energy distribution and selling activities, which are obliged to achieve energy savings rates per year by Energy Efficiency Titles (EET), well known as 'white certificates.'

Government and public bodies play a strategic role as 'a best customer' or as a preferable 'superconsumer' in energy markets. Moreover, they provide an exemplary model of best practice for all citizens and energy consumers who

\footnotetext{
${ }^{10}$ An overview of the implementation status within EU ( 28 countries) with updated data is included into the European Commission Report (2018).
} 
share with them the same condition (primus inter pares). Consequently, it is necessary to develop a parallel reasoning on duties of both private and public consumers. On the contrary, it does not deal with duties of big enterprises regarding energy diagnoses (art. 8 of Legislative Decree no. 102/2014), but this topic is not strictly functional compared to the concept of CSR studied here.

From the above-mentioned sources it is possible to extract, synthetically, some new duties of the 'superconsumer' (i.e. public bodies) within the energy market, as follows:

1) the duty to contribute to achieve energy savings rates of central government buildings as planned each year (art. 3 of Legislative Decree no. 102/2014);

2) the duty to enhance energy efficiency on owned or occupied central government buildings (art. 5, par. 10) also by Energy Performance Contracting (EPC);

3) the duty to make agreements for buying new real estate assets or lending the same in respect of minimal requirements of energy efficiency fixed in the attachment 1, Legislative Decree no. 102/2014, to verify through the certificate of energy performance (art. 6, pars. 1 and 1-bis);

4) the duty to buy goods and services through procurement procedures if over a determined threshold (art. 28 of Legislative Decree no. 163/2006) which provide Minimal Environmental Criteria (CAM) fixed for each product category by the Action Plan for Environmental Sustainability Consumptions in the Public Sector (2008) (PAN GPP), as provided by article 6, para. 2.

The Energy Efficiency Decree has to be coordinated with the third package of Directives $(2009 / 72 / \mathrm{EC}$ on internal market of electrical energy and $2009 / 73 /$ EC on gas internal market) subsequently implemented in Italy by the Legislative Decree 1 June 2011, no. 93, realising the empowerment of consumers rights. These Directives have paid attention to consumers empowerment, firstly, where a customer wishes to change supplier (while respecting contractual condition) the change is effected by the operator(s) concerned within three weeks. Secondly, customers are entitled to receive all relevant consumption data promptly and frequently. Lastly, customers need tools to put in place an alternative dispute resolutions (ADR) system based on the participation of both energy suppliers and users.

The right to be informed, so empowered, appears settled to exercise the right of portability that consumers may use to achieve different goals: a purely egoistic calculation for economic savings, or ethical and altruistic evaluations to prefer green energy providers. The right to be informed appears settled also to allow consumers to evaluate their own eco-footprint or carbon-footprint 
(Vanderheiden, 2010), therefore they can make responsible, ecological and sustainable choices in order to estimate the if, how, when and how much of energetic consumptions.

Indeed, thanks to intelligent metering systems or smart energy distribution networks, it is possible to know and monitor one's own consumptions and consequently to be much more responsible for energy sources using (Lavrijssen, 2014).

In conclusion, the above-mentioned rights in the energy sector are useful to decline additional consumers duties corresponding to consumers rights and specifically:

1) the duty to monitor consumption information provided by gas and energy distributors;

2) the duty to know their own energy consumption habits and eco-footprint;

3) the duty to be informed on competitive energy distributor offerings.

These three duties will function both to enhance an increasingly responsible energy resources consuming (if, how, when and how much consumption of light and gas) and to make consumers aware of the choices for portability of energy and gas suppliers in the perspective of a complete liberalisation within the energy and gas distribution market in the short or middle term.

Energy saving measures are, among others, energy performance contracting or EPC (Benanti, 2017; Maugeri, 2014; Parola et al., 2015; Pennasilico, 2014) introduced by Dir. 2012/27/UE (25 October 2012) that is defined as "a contractual arrangement between the beneficiary and the provider of an energy efficiency improvement measure, verified and monitored during the whole term of the contract, where investments (work, supply or service) in that measure are paid for in relation to a contractually agreed level of energy efficiency improvement or other agreed energy performance criterion, such as financial savings" (art. 1, no. 27)/

The same definition was implemented, substantially identical, in Italy in art. 2 of Legislative Decree no. 102/2014 which amended the previous definition by Legislative Decree no. 115/2008 (introduced by implementing Directive 2006/32/EC which for the first time introduced EPC in Europe and in Italy).

Furthermore, the frame of contractual instruments for responsible using of energy sources is completed with certificates of energy performance (Bonnì, 2014) that can consist of a very important benchmark in comparative and objective evaluation of real estate assets for potential buyers and borrowers, where not even a pivotal or decisive criterion exists, although it is considered by many as a simple formal fulfilment to avoid sanctions at the moment of buying or lending assets (art. 15 of Legislative Decree no. 192/2005). 
Energy performance certificates have limited validity in time and are subject to compliance with maintenance obligations of heating systems and updating to any restructuring or modification of the property, according to art. 6 , par. 5 of Legislative Decree no. 192/2005.

This sector presents a set of different duties of private owners, buyers and tenants of real estate assets which can be listed as follows:

1) the duty to periodic maintenance of heating systems and update of booklets of boilers by users and property owners;

2) the duty to update periodically energy performance certificates, according to fixed legal timing;

3) the duty of building owners to arrange energy performance certificate in case of selling the building, as a starting step of sales appointment assignment;

4) the duty of real estate brokers to give information about building energy class in their sales or rental announcements;

5) the duty of owners who sell their property through real estate brokers to give energy performance certificate in original version to the notary at the time of signing the deed of sale and enclose it with the act.

The energy sector in Italy, according to EU rules, is burdened by obligations more than other 'superconsumers' to reduce energy consumption through mandatory efficiency programmes for buildings of public bodies or elective private citizens measures that include state incentives or financial support.

The total visible outcome is a legal strategy that moving from the bottom, namely from the consumers of energy, and imposing over them a gradual reduction in consumption through the efficiency programmes, is leading to a double result: in the short run, alignment with the Europe Strategy 2020 by reducing central government energy consumption and, in the long run, it provokes spontaneous socially responsible choices by enterprises and citizens-consumers investing in building renovation and achieving better energy performance.

\subsection{Consumers' duties in the Italian Environment Code and Public Contracts Code}

The last step in our framework of Consumer Social Responsibility as binding legal principle in the European and Italian systems can be spotted in the Environment Code, Legislative Decree no. 152, 3 April 2006, as amended by Legislative Decree 4, 16 January 2008, which introduced two new articles 3-ter and 3-quater with a huge systematic impact because they express fundamental principles for the whole of Environmental Law. 
Due to the statement of principles of environmental prevention, precaution and 'polluter pays' charged to all public and private bodies and individuals too (art. 3-ter), as well as the principle of sustainable development, they have a strategic importance in the Code (Cafagno, 2008; Falcone, 2008; Masera, 2016; Rizzioli, 2012) since they oblige every human activity to "guarantee the satisfaction of actual generations needs cannot comprise life quality and possibilities of future generations" (art. 3-quarter of Environment Code), therefore they have a strategic importance in the Code (Cafagno, 2008; Falcone, 2008; Masera, 2016; Rizzioli, 2012).

These principle statements, which could be included in a lato sensu concept of socio-economic public order, modelled by the technique of legal standards, have a number of consequences affecting every human activity for citizens as well as private and public collective entities, that could be more or less structured as follows:

1) the duty to respect all detailed rules, also according to administrative and local regulations, which shall introduce the implementing Environmental Code (think of the separate collections of waste, prohibition of illegal dumping, provision on the time of conferment and so on);

2) the duty to do negotiating activity between both private people and public administrations not in contrast with the aforementioned principles of economic-social public order, whose violations could probably also cause the illegality of the contract;

3) the duty to compensate damages deriving from the violation of the "polluter pays' rule;

4) the duty to pay administrative or criminal sanctions resulting from the violation of the abovementioned environmental standards, depending on their order and degree.

Among many contracting activities particularly significant examples could be found in the case of ecological contract and green procurements related to each other as genus to species. Indeed, the new Italian Code of Public Contracts (articles 34 e 71 of Legislative Decree no. 50, 18 April 2016) as amended by corrective Decree (Legislative Decree no. 56, 19 April 2017) confirmed those provisions on green economy (already implemented by the so-called Environmental Related to the Stability Law 2014 inside the previous Public Contracts Code, Legislative Decree no. 163, 12 April 2006). They consist of mandatory clauses, called Minimum Environmental Criteria (MEC) or more usually 'green clauses', or Green Public Procurement Criteria (GPP), for each type of purchase 
within the sphere of the commodity categories identified, which public contracting authorities have to insert in public tender. We have just seen that also the Decree on energy efficiency requires to meet MEC in public tenders for services and supplies over a specific threshold.

Specifically, Art. 34 of Public Contracts Code provides for "The public contracting authorities contribute to achieve environmental targets identified under the national Action Plan for Environmental Sustainability of Public Sector Consumptions (2008), by introducing in tender documents and public procurement procedure at least contracting clauses which meet the minimum environmental criteria introduced by the Ministry of the Environment Decree, in accordance with those specifically set up by article 144 referring to services and supplies in public catering and food providing sectors. The Minimum Environmental Criteria so defined by the Decree mentioned in the first paragraph are taken into account also for drafting tender documents in application of the most economically advantageous tender criterion, in accordance with article 95, para. 6". That implies public authorities should select offers adopting the most economically advantageous tender criterion rather than the lower cost criterion because only the former is able to balance different and contrasting concerns such as environmental protection practised by meeting MEC with higher costs for contracting companies and economic interests of public bodies directed at containing public costs (De Leonardis, 2017).

It may be assumed, by the exclusion of the lower cost criterion, that there is both an opposition between economic and ecological interests strengthened by the aforementioned law, and the awareness of the pivotal role that public contracting and public bodies as 'superconsumers' may have to encourage companies to do business and make profits at the same time (and almost unknowingly) meeting environmental protection objectives (De Leonardis, 2017).

To sum up, provisions on the mandatory adoption of Minimum Environmental Criteria in green public procurement confirm the existence of a strategy to realise corporate social responsibility targets starting from a bottom-up perspective, namely beginning to oblige 'superconsumers' as public administrations to make legal choices in the tender sector able to encourage companies to invest in ecologically innovatory solutions and to direct the suppliers towards voluntary corporate socially responsible choices. 


\section{Conclusions}

In conclusion, this research aims at contributing in CSR debate, proposing an original bottom-up perspective and a linkage with consumers' European law, seen as a leverage capable of orienting business towards ethical behaviour.

Starting from the demonstration that there is an inseparable linkage between consumers' rights and their legal duties, we have shown that the empowerment of consumers rights unavoidably leads on to empowerment of consumers legal duties and responsibilities, which is the flywheel of voluntary corporate social responsibility. The existing literature has highlighted the possibility to infer consumers' ethical duties from legal rights, while our study overcomes this finding and affirms the existence of a legal consumer responsibility. This is one of the distinctive and original contributions of this research in comparison with the existing literature findings.

The second research step has consisted of collecting pieces of evidence that have confirmed the idea of a European strategy to inspire voluntary sustainable choices by firms and corporations, imposing a legal social responsibility over consumers from the bottom. Our legal investigation has selected three sectors of EU consumer legislation: financial market, energy, environment and public procurement.

The concept of 'responsible consumer,' which has arisen deepening the second-generation EU consumer legislation in these fields, leads the enterprises to make sustainable choices in business to match consumer preferences while still making profits. Among consumers a strategic role is entrusted to the 'state' and most generally all public bodies, that we call 'superconsumers' during this study, which are responsible for fulfilling the objectives of saving energy (expected in the 'Europe Strategy 2020') and increasing the sector of green procurements. Cases concerning duties of 'superconsumers' can be deemed the clearest example of what we believe is the Consumer Social Responsibility.

These findings are applicable to all EES countries, especially the part relating to energy and public procurement sectors, since they take origin from European legislation which determines common targets to achieve for any EU country. Nevertheless, each country has a different process of implementation of European legislation within the national boundaries, therefore a specific case (the Italian one) is provided as an applied model in the fields of finance, environment and public procurement as well. 
What is universally applicable in EES there is the highlighted tendency to impose legal duties over consumers, particularly 'superconsumers,' to obtain an orientation of business towards sustainable goods and services as well as more public and private investments in a socially responsible direction, while specific laws and rules may be different from state to state as are singular instruments to accomplish this goal.

The research may offer a new perspective for studying CSR in connection with consumer law to juridical and economic researchers; moreover, it can provide practitioners and businessmen with some confirmation about the development path of a more profitable European area to invest in innovation and research following the development line of consumers' duties. For example, the energy sector investigation, in this paper, points out the future development of green and renewable sources of energy and shows the reasons of the future increasing demand of these goods and services primarily from states, public entities and public administrations.

The most significant limitation of this study is its restriction on investigating only three sample domains among larger sectors within EU consumer law and preferably Italian law, under the specific juridical perspective. A subsequent development of this research or further research might fill this gap by broadening either the investigation field or the research methodology using a multidisciplinary approach (e.g. both economic and legal). A future implication of our research could be an investigation on the final data of national savings in the energy sector after the deadline 2020 imposed by EU authority for studying how the EU Strategy 2020 has modified European business of great, middle and small enterprises and whether substantial modification in sustainable investments is related to legal duties over consumers or superconsumers.

The originality of our research lies in the circumstance that there are no previous studies in the Italian and European literature concerning the role of consumer law in affecting CSR. So far the development process in studying CSR has been centred on two legal issues: the enforcement of ethical duties and the gradual incorporation of previous ethical duties in later legal ones. Therefore, we propose to move the research focus on legal duties of consumers to guarantee a more effective enforcement of sustainable business, maintaining its voluntary nature. 


\section{Acknowledgements}

I am sincerely grateful to Richard O. Zerbe and Nicolò Muciaccia who corrected this article and contributed to achieve the first version with their suggestions. Additionally, I thank the anonymous reviewers and the editors of JEM who suggested those improvements which have defined the final version of this paper. Nonetheless, the responsibility for ideas expressed and the mistakes therein are, obviously, solely mine.

\section{References}

Action Plan for Environmental Sustainability of Consumption in the Public Administration Sector (or National Action Plan on Green Public Procurement - GPP NAP), Inter-Ministerial Decree, 11 April 2008, amended by Ministry of Environment Decree, 10 April 2013, Retrieved from www.minambiente.it/pagina/piano-azionenazionale-sul-gpp

Assonime. (2016). La disciplina delle società benefit [The discipline of the society benefit]. Circolare no. 19 del 20 giugno 2016. Diritto Societario. Retrieved from http://www. societabenefit.net/wp-content/uploads/2017/02/Assonime-Benefit-Corporation.pdf

Acconci, P. (2009). La promozione della responsabilità sociale di impresa nel diritto internazionale [Promotion of the Corporate Social Responsibility in international law]. In P. Acconci (Ed.), La responsabilità sociale di impresa in Europa [The Corporate Social Responsibility in Europe] (pp. 3-23). Napoli: Edizioni Scientifiche Italiane.

Angelici, C. (2011). Responsabilità sociale dell'impresa, codici etici ed autodisciplina [Corporate social responsibility, ethical codes and self-discipline]. Giurisprudenza commerciale, 2(I), 159-176.

Angelici, C. (2018). Divagazioni sulla "responsabilità sociale" d'impresa [Digressions on the corporate "social responsibility"]. Rivista delle società, 1, 3-28.

Annunziata, F. (2015). La disciplina del mercato mobiliare ( $7^{a}$ edizione) [Securities Market Regulation (7th edition)]. Torino: G Giappichelli editore.

Arena, T. (2008). Social Corporate Governance and the problem of mission drift in socially-oriented microfinance institutions. Columbia Journal of Law \& Social Problems, 41(3), 269-316.

Beck, U. (1997). Was ist Globalisierung? Irrtümer des Globalismus - Antworten auf Globalisierung [What is globalization? Errors of globalism - answers to globalization]. Frankfurt am Main: Suhrkamp Verlages.

Benanti, C. (2017). "Energy Performance Contract": il contratto di rendimento energetico o di prestazione energetica ["Energy Performance Contract": The contract of energy efficiency or energy performance]. Osservatorio del diritto civile e commerciale, 6(2), 403-438. 
Bonini, M. (2015). Verso 1 "Unione dell'energia": la natura "strategica" della politica energetica, al crocevia fra relazioni internazionali e approvvigionamento universale [Towards the "Energy Union": "strategic" role of energetic policy, at the crossroads between International relations and universal supply]. Rivista italiana di diritto pubblico comunitario, 2(2), 685-693.

Bonnì, G. (2014). Attestato di prestazione energetica e tutela negoziale [Certificates of energy performance and negotiating protection]. In M. Pennasilico (Ed.), Manuale di diritto civile dell'ambiente [Handbook of environmental civil law] (pp. 236-242). Napoli: Edizioni Scientifiche Italiane.

Cafagno, M. (2008). Sub artt. 3-ter \& 3-quater. In G. Bottino et al. (Eds.) Codice dell'ambiente. Commento al D.lgs. 3 aprile 2006, n. 152, aggiornato alla Legge 6 giugno 2008, n. 101 [Environmental Code. Comment to the Legislative Decree 3 April 2006, no. 152, updated to the Law 6 June 2008, no. 101] (pp. 81-92). Milano: Giuffrè.

Capriglione, F. (1997). Etica della finanza e finanza etica [Ethics of finance and ethical finance]. Bari: Cacucci editore.

Carroll, A. B. (1991). The pyramid of Corporate Social Responsibility: Toward the moral management of organizational stakeholders. Business Horizons, 34(4), 39-48.

Communication of European Commission, COM(2010) 639 final, 10.11.2010, Energy 2020. A strategy for competitive, sustainable and secure energy.

Communication of European Commission, COM(2018) 97 final, 8.3.2018. Action Plan: Financing Sustainable Growth.

Consob Deliberation 15861, 30 May 2007.

Costi, R. (2011). Banca etica e responsabilità sociale delle banche [Ethical bank and social responsibility of banks]. Banca Borsa Titoli di Credito: rivista di dottrina e giurisprudenza, 64(2), 165-180.

Cseres, K., \& Schrauwen, A. (2012). Empowering consumer-citizens: Changing rights or merely discourse? (Working Paper Series, No. 3). Amsterdam: Amsterdam Centre for European Law and Governance. Retrieved from http://ssrn.com/abstract $=2154869$

De Leonardis, F. (2017). Economia circolare: saggio sui suoi tre diversi aspetti giuridici. Verso uno Stato circolare? [Circular economy: Essay on its three different juridical aspects. Towards a circular state?]. Diritto amministrativo: rivista trimestrale, 25(1), 163-207.

Denozza, F. (2013). Le aporie della concezione volontaristica della CSR [The aporias of CSR voluntaristic conception]. In V. Di Cataldo \& P. M. Sanfilippo (Eds.), La responsabilità sociale dell'impresa: in ricordo di Giuseppe Auletta [The corporate social responsibility: in memory of Giuseppe Auletta] (pp. 49-66). Torino: G Giappichelli editore.

Denozza, F., \& Stabilini, A. (2017a). Principals vs principals: The twilight of the "agency theory". Italian Law Journal, 3, 511-532. Retrieved from http://theitalianlaw journal.it/data/uploads/3-italj-2-2017/pdf-singoli/511-denozza-stabilini.pdf 
Denozza, F., \& Stabilini, A. (2017b). Società benefit nell'era dell'investor capitalism [The benefit corporation in the era of the investor capitalism]. Rivista Orizzonti del diritto commerciale. Retrieved from http://rivistaodc.eu/media/74709/denozz astabilini.pdf

Directive 2006/32/EC, 5 April 2006, on energy end-use efficiency and energy services (no longer in force)

Directive 2009/72/EC, 13 July 2009, concerning common rules for the internal market in electricity.

Directive 2009/73/EC, 13 July 2009, concerning common rules for the internal market in natural gas.

Directive 2012/27/EU, 25 October 2012, on energy efficiency.

Directive 2013/34/EU, 26 June 2013, on the annual financial statements, consolidated financial statements and related reports of certain types of undertakings.

Directive 2014/95/EU, 2 October 2014, amending Directive 2013/34/EU as regards disclosure of non-financial and diversity information by certain large undertakings and groups.

Directive 2016/97/EU, 20 January 2016, on insurance distribution (recast).

ESMA 35-43-1163, Guidelines on certain aspects of the MiFID II suitability requirements. (2018). Last update 6 November 2018. Retrieved from https://www.esma. europa.eu/sites/default/files/library/esma35-43-1163_guidelines_on_certain _aspects_of_mifid_ii_suitability_requirements_0.pdf

Europe 2020 Strategy, European Council Conclusions, 17 June 2010, from http://ec. europa.eu/eu2020/pdf/council_conclusion_17_june_en.pdf.

European Commission Report. (2018). EU energy in figures 2018. Retrieved from https://ec.europa.eu/energy/en/data/energy-statistical-pocketbook

European Council Conclusions, 17 June 2010, Europe 2020 Strategy, Retrieved from http://ec.europa.eu/eu2020/pdf/council_conclusion_17_june_en.pdf

Falcone, M. (2008). Principi ambientali di diritto comunitario [Environmental principles of Community Law], In A. Buonfrate (Ed.), Codice dell'ambiente e normativa collegata. Commentario [Environmental Code and related legislation] (pp.13-32). Torino: Utet Giuridica.

Fliess, B., Lee, H.-J., Dubreuil, O. L., \& Agatiello, O. R. (2007). CSR and trade: Informing consumers about social and environmental conditions of globalised production. Part I. (OECD Trade Policy Papers, No. 47). Paris: OECD Publishing. https://doi. org/10.1787/246322000033

Foltyn-Zarychta, M., \& Zerbe, R. O. (2019). The economics of CSR: The role of citizenconsumer mix in the Social Responsible Investing. In M. Castellaneta \& F. Vessia (Eds.), La Responsabilità Sociale d'Impresa fra diritto internazionale e diritto societario [Corporate Social Responsibility between international and company law] (pp. 79-110). Napoli: Edizioni Scientifiche Italiane.

Freeman, R. E. (1984). Strategic management: A stakeholders approach. Boston: Harpercollins College. 
Hilton, M. (2005). The duties of citizens, the rights of consumers. Consumer Policy Review, 15(1), 6-12.

Lavrijssen, S. A. C. M. (2014). The different faces of energy consumers: Towards a behavioral economics approach. Journal of Competition Law and Economics, 10(2), 257-291. https://doi.org/10.1093/joclec/nht046

Law no. 208/2015, 28 December 2015 - 2016 Stability Law.

Legislative Decree no. 385/1993, 1 September 1993, Single Banking Text (TUB).

Legislative Decree no. 58/1998, 24 February 1998, Consolidate of Finance Act (TUF).

Legislative Decree no. 192/2005, 19 August 2005, Implementation of the Directive 2002/91/EC on the energy efficiency in building.

Legislative Decree no. 152/2006, 3 April 2006, Environment Code.

Legislative Decree no. 163/2006, 12 April 2006, Public contracts Code on the implementation of Directives 2004/17/EC and 2004/18/EC.

Legislative Decree no. 115/2008, 30 May 2008, Implementation of the Directive 2006//32/EC on energy end-use efficiency and energy services.

Legislative Decree no. 93/2011, 1 June 2011, Implementation of the Directives 2009/72/EC, 2009/73/EC and 2008/92/EC concerning common rules for the internal market in electric energy, natural gas and a Community procedure to improve the transparency of gas and electricity prices charged to industrial end-users.

Legislative Decree no. 102/2014, 4 July 1014, Implementation of the Directive 2012/27/EU on the energy efficiency.

Legislative Decree no. 50/2016, 18 April 2016, Code of Public Contracts, amended by corrective Legislative Decree no. 56/2017, 19 April 2017.

Legislative Decree no. 141/2016, 18 July 2016, Integrative dispositions to the Legislative Decree no. 102/2014.

Legislative Decree no. 254/2016, 30 December 2016, Implementation of the Directive 2014/95/EU amending Directive 2013/34/EU as regards disclosure of non-financial and diversity information by certain large undertakings and groups.

Libertini, M. (2013, November). Economia sociale di mercato e responsabilità sociale d'impresa [Social market economy and corporate social responsibility]. Rivista Orizzonti del diritto commerciale, 1. Retrieved from http://odc.seminabit.com/ media/23041/libertini_-responsabilit_sociale_dell_impresa.pdf

Li, L. W. (2019, March). Mandatory Corporate Social Responsibility? Legislative innovation and judicial application in China. Forthcoming in American Journal of Comparative Law. Retrieved from https://ssrn.com/abstract $=3361448$

Malaguti, M. C., \& Salvati, G. G. (2017). La responsabilità sociale d'impresa [The corporate social responsibility]. Padova: Cedam.

Maugeri, M. (2014). Il contratto di rendimento energetico e i suoi "elementi minimi" [Energy performance contracting and its "minimum elements"]. La Nuova giurisprudenza civile commentata, 30(9), 420-425. 
Masera, S. R. (2016). Principio "chi inquina paga", obblighi di bonifica e di messa in sicurezza ["Polluter pays" principle, remediation and safety duties]. Urbanistica e appalti, 6, 721-728.

Micheletti, M. (2002). Consumer choice as political participation. Statsvetenskaplig Tidskrift, 105(3), 218-234.

Miller, R. L., \& Stafford, A. D. (2009). Economic education for consumers. Boston, Massachusetts: Cengage Learning.

OECD Guidelines for Multinational Enterprises. (2011). Paris: OECD. Retrieved from http://www.oecd.org/daf/inv/mne/48004323.pdf

Parola, L., Armoni, T., \& Granata, S. (2015). I contratti di efficienza energetica. Profili regolamentari e prassi [Energy performance contracting. Regulatory profiles and practice]. I Contratti, 5, 517-532.

Pellegrini, M. (2013). Regole di comportamento e responsabilità degli intermediari [Behavioural rules and responsibility of intermediaries]. In F. Capriglione (Ed.), I contratti dei risparmiatori [The savers' contracts] (pp. 187- 220). Milano: Giuffrè.

Pennasilico, M. (2014). Il contratto di rendimento energetico (Energy performance contract). In M. Pennasilico (Ed.), Manuale di diritto civile dell'ambiente. Temi e problemi di diritto dell'ambiente. [Handbook of environmental civil law. Themes and issues of environmental law] (pp. 242-249). Napoli: Edizioni Scientifiche Italiane.

Perrone, A. (2010), Gli obblighi informativi [Informative obligations]. In R. D'Apice (Ed.), L'attuazione della Mifid in Italia [The implementation of MIFID in Italy] (pp. 499-510). Bologna: il Mulino.

Regulation (EC) no. 713/2009, 13 July 2009, establishing an Agency for the Cooperation of Energy Regulators.

Regulation (EC) no. 714/2009, 13 July 2009 on conditions for access to the network for cross-border exchanges in electricity.

Regulation (EC) no. 715/2009, 13 July 2009, on conditions for access to the natural gas transmission networks.

Regulation (UE) no. 211/2011, 16 February 2011, on the citizens' initiative.

Rizzioli, S. (2012). Sub artt. 3-ter \& 3-quater. In L. Costato \& F. Pellizzer (Eds.), Commentario breve al codice ambiente [Short Commentary on the Environment Code] (pp. 14-19). Padova: Cedam.

Schrader, U. (2007). The moral responsibility of consumers as citizens. International Journal of Innovation and Sustainable Development, 2(1), 79-96.

Sciarrone Alibrandi, A. (2009). La "consulenza in materia di investimenti": profili di novità della fattispecie ["Investment advice": New profiles of this particular case]. In L. Frediani \& V. Santoro (Eds.), L'attuazione della Direttiva MIFID [The implementation of MIFID Directive] (pp. 73-100). Milano: Giuffrè.

Sciarrone Alibrandi, A., \& Macchiavello, E. (2018). Sub art. 111-bis TUB. In F. Capriglione (Ed.), Commentario al Testo Unico delle Leggi in materia bancaria e creditizia [Commentary on the consolidated text on banking and credit laws] (Vol. 2, pp. 1643-1655). Padova: Cedam. 
Thornton, R. (2008). Ethical investments: A case of disjointed thinking. The Cambridge Law Journal, 67(2), 396-422. https://doi.org/10.1017/S000819730800038X

Vanderheiden, S. (2010). Taking responsibility as consumers and citizens: Individual responses to environmental crises. In APSA 2010 annual meeting paper (pp. 7-28). Washington, DC: American Political Science Association. Retrieved from https:// www.researchgate.net/publication/228211676 